\title{
EPERYTHROZOON OVIS INFECTIONS OF SHEEPAND GOATS IN SHALATEEN, ABU-RAMAD AND HALAEEB, RED SEA GOVERNORATE, EGYPT
}

\author{
OSMAN M. MAHRAN and SOUZAN G. GHATTAS
}

Parasitology Dept. Animal Health Research Institute, ARC, Giza

(Manuscript received 21 March 2016)

\begin{abstract}
$\Lambda$ $\mathrm{n}$ outbreak occurred in sheep and goats in triangular area (Shalateen -Abu-Ramad and Halaeeb), Red Sea Governorate, Egypt was described between January to December 2013.This outbreak showed clinical signs characterized by fever, in appetence, emaciation, anemia, icterus and ill-thrift. Clinical signs are most likely to be observed in young suckling and weaner animals. It is shown to be a complex problem attributable to many causes, some of which can be eliminated by supplementary feeding, drenching, vaccination, dipping and management. However, severe prolonged anemia accompanied by the development of ill-thrift still present in 248 animals (165 sheep and 83 goats). Infection with Eperythrozoon ovis was demonstrated in $21.42 \%$ and $12.50 \%$ of lambs and kids, $41.37 \%$ and $28.75 \%$ of weaner sheep and goats and $10.75 \%$ and $8.51 \%$ of adult sheep and goats respectively. When the general prevalence was analyzed by age, it was observed that weaners were mostly affected and disease was highly observed during winter and summer. Hematological examination showed macrocytic hemolytic anemia, with anisocytosis, poikilocytosis and marked left shift in erythrocyte maturation. Infected sheep and goats showed significant reduction in values of $\mathrm{Hb}, \mathrm{PCV}$ and $\mathrm{RBC}$ while leukocytic count appeared slightly elevated. The main pathological changes in E. ovis infection were an increase in size of spleen at the peak of parasitaemia and an increase in liver size. Haemosiderin was present in livers, kidneys and spleens of all infected sheep and goats at the peak and late stages of parasitaemia.

Key words: Eperythrozoon ovis - Incidence - Hematology Clinical significance - Histopathology.
\end{abstract}

\section{INTRODUCTION}

Eperythrozoonosis is a parasitic disease caused by Eperythrozoon parasitizing on the erythrocyte surface, plasma and bone marrow of sheep, goats and cattle and transmitted by blood sucking arthropods (Sheriff et al., 1966). Sheep and goats parasitized by Eperythrozoon have the symptoms of anemia, icterus, fever and reproductive disorders. Deaths may occur in severely affected young sheep and goats especially if they are stressed by yarding. Losses of up to $30 \%$ of the flock have occurred in these circumstances (Brun et al., 2007). Eperythrozoon causes further losses when infected carcasses are condemned because of jaundice (Veale and 
Nicholls, 1986). Infections are frequently unapparent and chronic. E. ovis in goats results in more severe disease (Mason and Statham, 1991). E. ovis has not been cultivated, diagnosis is made by detection of organisms on erythrocytes in Romanowsky type or Prussian blue stained blood smears and by serological methods. Parasitism of erythrocytes often occurs at a low level and is transient; detection requires examination of repeated blood smears (Gulland et al., 1987). The aim of this study is to record the incidence, clinical significance, hematological and pathological changes of Eperythrozoon ovis infection in sheep and goats.

\section{MATERIALS AND METHODS}

\section{Animals:}

A total of 248 animals [165 sheep (14 lambs 1-4 months, 58 weaner $>4-12$ months and 93 mature $>12$ months) and 83 goats ( 8 kids, 28 weaner and 47 mature)] from the triangular area (Shalateen, Abu-Ramad and Halaeeb) were included in this study between January to December 2013. These animals were subjected to careful clinical and laboratory investigations.

\section{Parasitological examination:}

Blood samples were collected with a sterile needle and syringe from the jugular vein of each animal showed symptoms of fever, in appetence, emaciation, anemia, icterus and ill-thrift. About $2 \mathrm{ml}$ of blood was collected from each animal into test tubes containing ethylene diamine tetra-acetic acid (EDTA) as anticoagulant. In all groups active infection was demonstrated by the examination of thick and thin blood films, stained with Giemsa stain. The mean value of parasitaemia was recorded according to Patricia and Harbutt, (1969). Percentage of infected RBCs was assessed by counting the number of parasites in erythrocytes present per 1000 cells at magnification of $\times 1000$ then divided by ten and expressed as percentage (Urquhart et al., 2003).

\section{Hematological examination:}

$\mathrm{Hb}, \mathrm{PCV}, \mathrm{RBC}$ and $\mathrm{WBC}$ were determined using the standard methods described by (Schalm et al., 1975). The MCHC, MCH and MCV were also calculated.

\section{Necropsy examination:}

Seven dead animals ( 5 lambs and 2 kids) and 2 live affected weaners were necropsied after slaughter. Parts from liver were fixed in $10 \%$ neutral buffered formalin, then embedded in paraffin, sectioned at $5 \mu \mathrm{m}$ and stained with Brussian blue according to Bancroft and Stevens (1993). 


\section{RESULTS}

Table (1) showed that the percentage of infection was higher in summer $(28.57 \%)$ and winter $(22.72 \%)$ in sheep and goats respectively. The lower percentages were in spring (17.5\%) and autumn (10\%) in the same animals. The clinical signs observed were fever, inappetance, emaciation, ill thrift, anemia, jaundice and death.

\section{Incidence of Eperythrozoon ovis:}

Eperythrozoon ovis infection was demonstrated in $21.42 \%$ and $12.50 \%$ in lambs and Kids, 41.37 and $28.57 \%$ in weaner sheep and goats and $10.75 \%$ and $8.51 \%$ in adult sheep and goats respectively (Table 2 ).

Table 1. Seasonal distribution of Eperythrozoon ovis in sheep and goats.

\begin{tabular}{|c|c|c|c|c|c|c|}
\hline \multirow{2}{*}{ Season } & \multicolumn{3}{|c|}{ Examined sheep } & \multicolumn{3}{c|}{ Examined goats } \\
\cline { 2 - 7 } & Total & $+\mathrm{ve}$ & $\%$ & Total & $+\mathrm{ve}$ & $\%$ \\
\hline Winter & 42 & 10 & 23.80 & 23 & 5 & 22.72 \\
\hline Spring & 40 & 7 & 17.5 & 19 & 2 & 10.25 \\
\hline Summer & 42 & 12 & 28.57 & 21 & 4 & 20 \\
\hline Autumn & 41 & 8 & 19.51 & 20 & 2 & 10 \\
\hline Total & 165 & 37 & 22.42 & 83 & 13 & 15.66 \\
\hline
\end{tabular}

Table 2. Incidence of Eperythrozoon ovis in different ages of sheep and goats.

\begin{tabular}{|c|c|c|c|c|}
\hline \multirow{2}{*}{\multicolumn{2}{|c|}{ Animals }} & $\begin{array}{c}\text { No. of examined } \\
\text { animals }\end{array}$ & $\begin{array}{c}\text { No. of infected } \\
\text { animals }\end{array}$ & \% of infection \\
\hline \multirow{4}{*}{ sheep } & lambs & 14 & 3 & 21.42 \\
\cline { 2 - 5 } & weaner & 58 & 24 & 41.37 \\
\cline { 2 - 5 } & Adult & 93 & 10 & 10.75 \\
\hline \multirow{2}{*}{ Total no. of sheep } & 165 & 37 & 22.42 \\
\hline \multirow{3}{*}{ Goats } & Kids & 8 & 1 & 12.5 \\
\cline { 2 - 5 } & weaner & 28 & 8 & 28.57 \\
\cline { 2 - 5 } & adults & 47 & 4 & 8.51 \\
\hline \multicolumn{2}{|c|}{ Total no. of goats } & 83 & 13 & 15.66 \\
\hline
\end{tabular}

\section{Morphological characters:}

Plate 1 and 2 showed that Eperythrozoon ovis was observed on the surface of erythrocytes as small cocci, spheres clustered bodies of approximately $0.5-1.0 \mu \mathrm{m}$ in diameter. These bodies attached to the perimeter of erythrocytes or found free 
floating between erythrocytes. In heavy infections, chains of the parasites surrounding the margin of the red cell, measuring about $1-3 \mu \mathrm{m}$ in diameter (plate 1 ).

\section{Hematological examination:}

Mean values of hematological parameters are presented in table (3). Infected sheep and goats showed significant reduction in the values of $\mathrm{Hb}, \mathrm{PCV}, \mathrm{RBC}$ while the leukocytic count is slightly elevated. Whereas, MCHC was in the same range. On the other hand, MCH and MCV were highly elevated.

Table 3. Mean hematological values of sheep and goats infected with Eperythrozoon ovis

\begin{tabular}{|l|c|c|c|}
\hline Indices & Mean Values & Range & Reference Range \\
\hline $\mathrm{Hb}(\mathrm{g} / \mathrm{dl})$ & 4.8 & $3.5-5.9$ & $9-14$ \\
\hline $\mathrm{PCV}(\%)$ & 12.6 & $10-17$ & $21-39$ \\
\hline $\mathrm{RBC}\left(\times 10^{6} / \mathrm{L}\right)$ & 2.8 & $1.4-3.5$ & $9-15$ \\
\hline WBC (X103/L) & 14.1 & $9.7-22.1$ & $4-11$ \\
\hline MCHC (\%) & 32.5 & $30-35$ & $29-35$ \\
\hline MCH (PG) & 18.9 & $17-23$ & $8-11$ \\
\hline MCV (fl) & 58 & $40-69$ & $28-40$ \\
\hline
\end{tabular}

\section{Parasitaemic status:}

The mean value of parasitaemia (count /1000 RBC) reached $0.48-4.52 \%$ with mean of $2.27 \% \pm 0.09$ in sheep and $0.29-2.9 \%$ with mean of $1.21 \% \pm 0.12$ in goats (Table 4). There was marked red cell anisocytosis and polychromatic. Red cells also showed spherocytosis and schistocytosis. These results were consistent with severe responsive macrocytic normochromic anaemia.

Table 4. Parasitaemia of E. ovis percent

\begin{tabular}{|c|c|c|}
\hline Animals & Range & Mean S.F \\
\hline Sheep & $0.48-4.52$ & $2.27 \pm 0.09$ \\
\hline Goats & $0.29-2.9$ & $1.21 \pm 0.12$ \\
\hline
\end{tabular}

\section{Postmortem examination:}

Postmortem examination of infected animals showed pale mucous membranes and various degrees of jaundice. Liver and spleen showed fine mottling and much enlarged with a prominent white pulp.

\section{Histopathology:}

The most consistent lesions were a moderate generalized periacinar necrosis of the liver, marked hyperplasia of the germinal centers and generalized severe haemosiderosis of liver and spleen. 


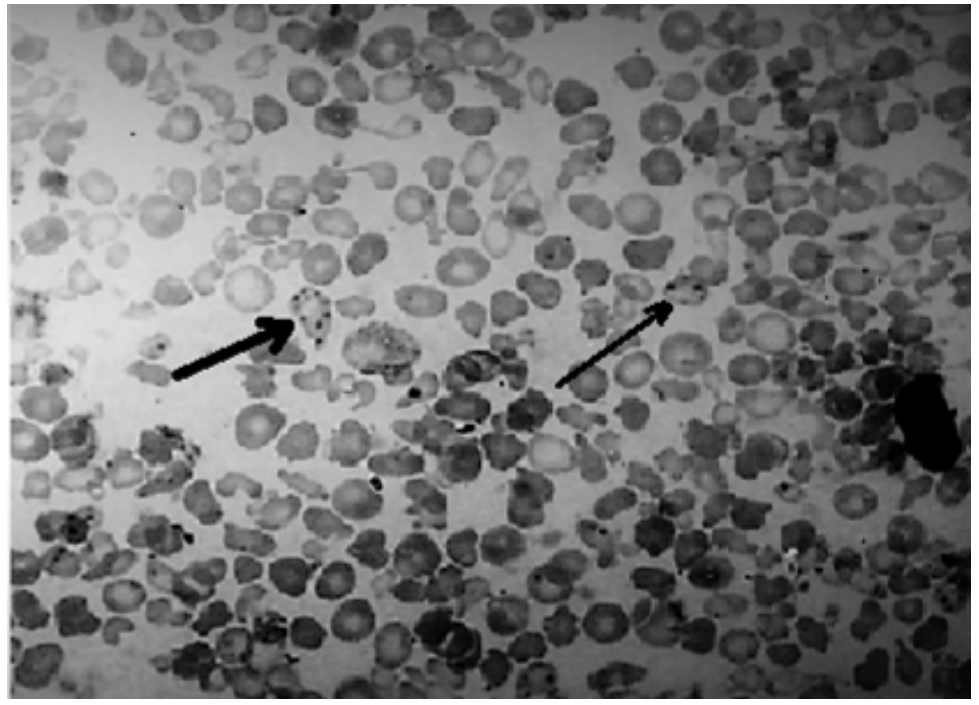

\section{Plate 1.}

Giemsa stained blood smear from weaner goat showing Eperythrozoon ovis with morphological alteration in some RBCs (x1000)
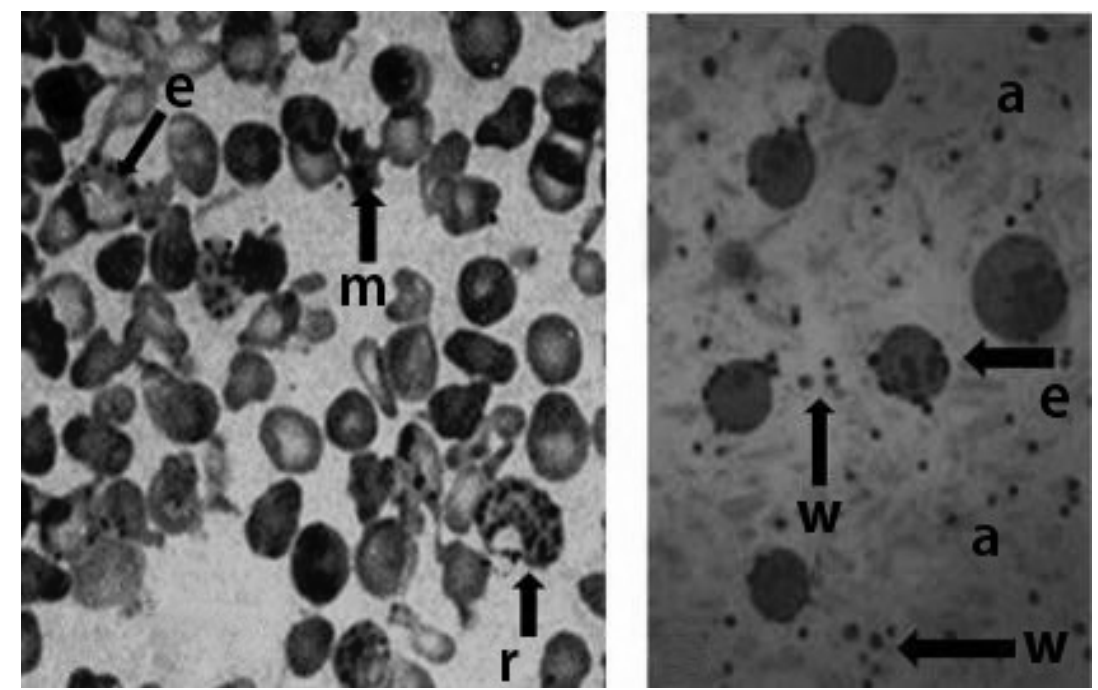

\section{Plate 2.}

Giemsa stained blood smear from weaner sheep showing Eperythrozoon ovis (x1200). Eperythrozoon organisms are attached to the perimeter of erythrocytes (e).

The large gaps between red cells indicate anemia (a).

Heavy infection with high parasitaemia between RBCs (w) and inside them ( $r$ ).

Morphological alteration in RBCs (anisocytosis and poikilocytosis) (m). 

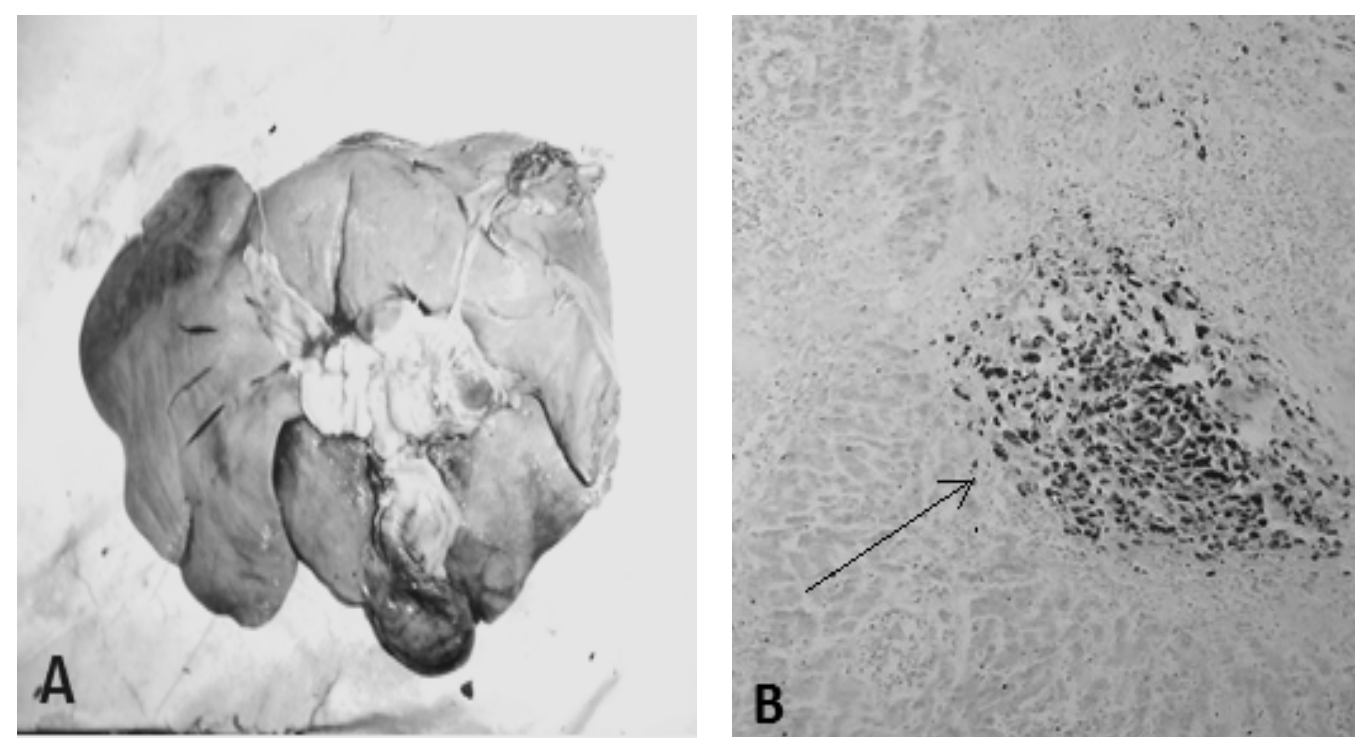

\section{Plate 3.}

(A): Liver of sheep infected with $E$. ovis showing severe jaundice.

(B) Haemosiderin in liver of sheep stained with Prussian blue (arrow) x20

\section{DISCUSSION}

Results of this investigation revealed Eperythrozoon ovis was demonstrated in $21.42 \%$ and $12.50 \%$ in lambs and kids, $41.37 \%$ and $28.57 \%$ in weaner sheep and goats and $10.75 \%$ and $8.51 \%$ in adult sheep and goats respectively. Al- Khalifa et al., (2009) recorded that infection with E. ovis was $2-9 \%$ in Saudi Arabia. In Australia Eperythrozoon infection was reported in $10 \%$ of weaner and $51 \%$ of adult sheep (Veale and Nicholls, 1986) and 40\% in Iraq (Hasan, 2012). The difference in percentage of infection may be due to the latent nature and the non-specific clinical symptoms of the disease. It seems likely that the prevalence of $E$. ovis in sheep and goats populations may be considerably greater than the number of clinical cases might lead one to suppose (Overas, 1969). Clinical outbreaks are most likely to be observed in young suckling and weaner animals characterized by fever, anemia, icterus, poor weight gain and depression. These results are in agreement with the results of other studies carried out in other countries (Mason and Statham, 1991 and Robson and Kemp, 2007). The high incidence of infection was recorded in winter and late summer. Our findings are in accordance with other workers (Sheriff, 1979 and Burroughs, 1988). Eperythrozoon ovis observed in this study could be due to the favourable environmental conditions for the survival and proliferation of the arthropods vectors such as fleas, mosquitos and ticks. Neimark and Ganter (2004) stated that the Eperythrozoon ovis in sheep and goats was transmitted mechanically 
by fleas and mosquitos. Ticks (Rhipicephalus) are vectors of Eperythrozoon for cattle. Also, transmission may occur via surgical procedures through blood contamination of instruments and needles during vaccination or treatment. E. ovis appeared as minute bluish coloured cocci, rings, spheres clustered on the surface of RBCs and found free in plasma. Brun et al., (2007) and Hasan, (2012) recorded similar results on this parasite. In the present study hematological studies showed marked decrease of total HB, PCV and RBCs concentration. Macrocytic hemolytic anemia, with anisocytosis, poikilocytosis and marked left shift in erythrocyte maturation were observed. The leukocytic count is slightly elevated and confirm the finding of other researchers. Sheriff, (1979) and Gullanad et al., (1987) reported Eperythrozoon ovis causes haemolytic anemia, reduced production and decreased exercise tolerance in sheep and goats. Fitzpatrick et al., (1998) reported that the infection with E. ovis can result in damage to red blood cells as the parasite is found attached to their surface or free in the plasma, and the consequence of a heavy infection particularly in young weaned lambs may be cause haemolytic anemia and death. Adejinmi (2004) reported that Eperythrozoon ovis is an organism that infect the red blood cells and may trick the body's immune system into thinking that these cells are foreign thus causing the immune system to destroy the cells. The destruction of red blood cells may lead to life-threatening anemia. The mean percent of parasitaemia of E. ovis were $2.27 \%$ and $1.21 \%$ in sheep and goats respectively. Wanphen (2015) mentioned that numbers of E. ovis ranging from 1-50, in highly dense parasitaemia. Parasitaemia develops during the pyretic stage at which time parasites can be found in great numbers on the red blood cells and in the plasma (Brun et al., 2007). The severity of anaemia and parasitaemia was variable. It is postulated that in such infection the host immune response may be expressed before infection is fully developed. It was also shown that there was a significant correlation $(p<0.01)$ between the maximum degree of anaemia and maximum degree of parasitaemia for all infected sheep and goats. For this reason the possibility of a direct effect by the parasite on the erythrocyte, contributing to the anaemia cannot be discounted. In case of Eperythrozoon infection, the mechanism of disease appears similar to that occurs of other blood parasites, where in immunemediated hemolysis within macrophages follows attachment of the organisms to erythrocytes (Harold et al., 2004). Gulland et al., (1987) recorded that infection of adult sheep with a single strain of Eperythrozoon ovis led to three different situations. First, the animal resisted the organism and no haematological changes occurred. Second, the host developed a controllable parasitaemia in which erythrocyte values fell shortly after peak parasitaemia and then returned to normal. 
Third, the host failed to control the parasitaemia and chronic low grade anaemia developed. In our study the main pathological features in E. ovis infection are mostly similar with Sutton (2011). This investigation indicates that $E$. ovis infection once present in a flock of sheep and goats may spread easily among them and that the infection seems to be persisting within the flock.

\section{REFERENCES}

1. Adejinmi. 2004. Studies on the blood parasites of sheep in Ibadan, Nigeria.African Journal of Biomedical Research, Vol. 7, No. 1, pp. 41-43.

2. Al-Khalifa, M.S., H.S. Hussein, F.M. Diab and G.M. Khalil. 2009. Blood parasites of livestock in certain regions in Saudi Arabia.Saudi J. Biol. Sci.; 16(2):63-67.

3. Bancroft, J. D. and A. Stevens. 1993. Theory and Practice of Histological Techniques, 3rd Ed. Long Man Group Limited.

4. Brun, H., H.Gronstol, H. Waldeland and B. Hoff. 2007. Eperythrozoon ovis infection in a commercial flock of sheep. Zentbl Veterinarmed. B44, 295-299.

5. Burroughs, G.W. 1988. The significance of Eperythrozoon ovis in ill-thrift in sheep in the Eastern Cape coastal areas of South Africa.J. S. Afr. Vet. Assoc.; 59(4):195-199.

6. Fizpatrick, R.C.J., L. Barron, H. Andrew and H. Thompson. 1998. Eperythrozoon ovis infection of sheep. Comp. Haemat. Internat. J.8: 230-234.

7. Gulland, F.M., D.L. Doxey and G.R. Scott. 1987. The effects of Eperythrozoo novis in sheep. Res. Vet. Sci.; 43(1):85-87.

8. Harold, N., H. Brent and G. Martin. 2004. Mycoplasma ovis comb. Nov. (formerly. Eperythrozoon ovis), an epierythrocytic agent of haemolytic anaemia in sheep and goats. International J. of Systematic and Evolutionary Micr.54, 365-37.

9. Hasan, M.H. 2012. Diagnosis of some blood parasites in cattle and sheep in Mosul, Iraq. Iraqi J. Vet. Sci., Vol. 26, 57-61.

10. Jacobson, R. 1996. Principles of validation of diagnostic assays for infectious disease. In manual of standards for diagnostic tests and vaccines, 3rd Ed. Office International des Epizooties, Paris, 8-15

11. Kreier, J. P. and M. Ristic. 1984. Genus III. Haemobartonella Tyzzer and Weinman 1939, 143AL; Genus IV. Eperythrozoon Schilling 1928, 1854AL.In Bergey's Manual of Systsematic Bacteriology, vol. 1, pp. 724-729.Edited by N. R. Krieg and J. G. Holt. Baltimore: Williams and Wilkins.

12. Mason, R. W. and P. Statham. 1991. Susceptibility of sheep and goats to Eperythrozoon ovis infection. Aust. Vet .J. 68, 116-117. 
13. Neimark, H. and M. Ganter. 2004. Mycoplasma ovis comb. nov. (formerly Eperythrozoon ovis), an epierythrocytic agent of haemolytic anaemia in sheep and goats. Int. J. Syst. Evol. Microbiol. 54, 365-371.

14. Overas, J. 1969. Studies on Eperythrozoon ovis infection in sheep. Acta. Vet .Scand . Suppl. 28, 1-48.

15. Patricia, R. and P. Harbutt. 1969. The incidence and clinical significance of Eperythrozoon ovis infections of sheep in Victoria. Australian Veterinary Journal 45: 493-499.

16. Robson, S. and B. Kemp. 2007. Eperythrozoonsis in sheep. [Internet] state of New South Wales: http://www.dpi.nsw-gov.au/primefacts.

17. Schalm, O.W., N.C Jain and E.J. Carrol. 1975. Veterinary Haematology, $3^{\text {rd }}$ Ed. Lea and Febiger, Philadephia pp. $15-81$.

18. Sheriff. 1979. Eperythrozoon ovis-a cause of anaemia, reduced production and decreased exercise tolerance in sheep. Aust. Vet. J.; 55(12):602.

19. Sheriff, D., K. H. Clapp and M. A. Reid. 1966. Eperythrozoon ovis Infection and the antiglobulin test. Austral.Vet. J., 42, 169 - 172.

20. Sutton, R.H. 2011. Observations on the pathology of Eperythrozoon ovis infection in sheep.N. Z. Vet. J.Vol. 26, Issue 9, p. 224-230.

21. Urquhart, G.M., J. Armour, J. L. Duncan, A.M. Dunn and F.W. Jennings. 2003. Veterinary Parasitology 2nd ed. Blackwell Science Ltd., Oxford; p 252.

22. Veale, P.I. and J.T. Nicholls. 1986. The prevalence of Eperythrozoon ovis infection in weaner and adult sheep in north eastern Victoria. Aust. Vet. J., 63(4):118-120.

23. Wanphen, S. 2015. Prevalence of anaplasmosis and eperythrozoonosis of goats in Satun Province in Thailand. J. Witthayasan Kasetsart Vol. 39, Issue 5, p.35-41. 


\section{إصابة الضأن والمعز بالإبيريثروزون فى شلاتين - أبورماد - حلايب بمحافظة البحر الاحمر، مصر}

\section{عثمان محمد مهزان و سوزان جرجس غطاس}

$$
\text { قسم الطفيليات - معرد بحوث صحة الحبوان - مركز البحوث الزراعية -الجيزة }
$$

ظهرت إصـابة الضأن و المعز بالإبيريثزوزون بمنطقة المنلث فــى شــلاتين وأبــو رمــاد

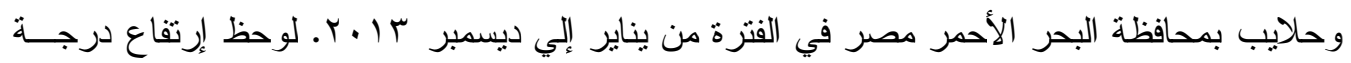

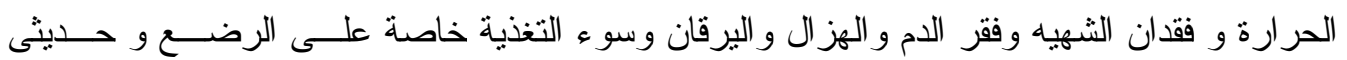

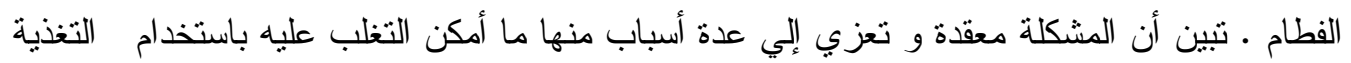

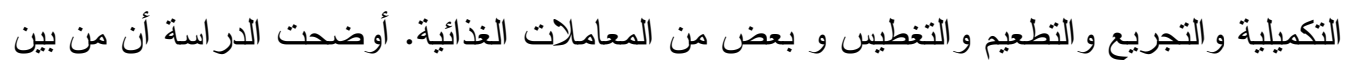

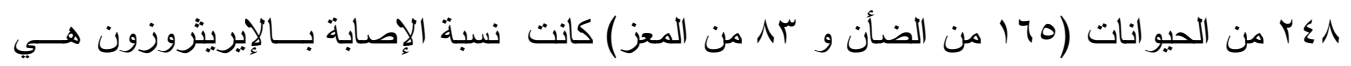

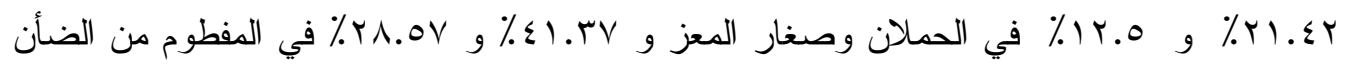

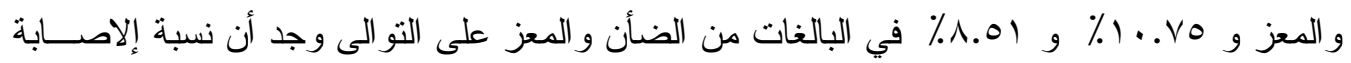

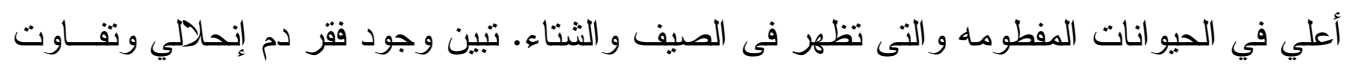

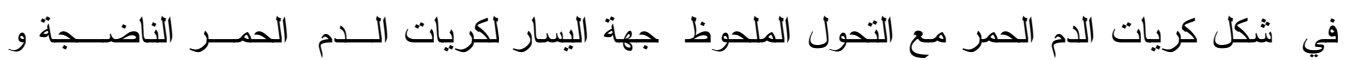

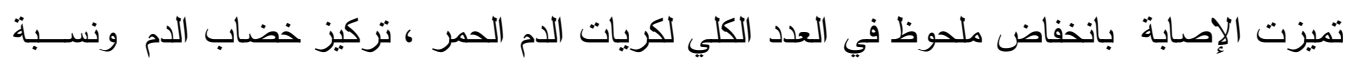

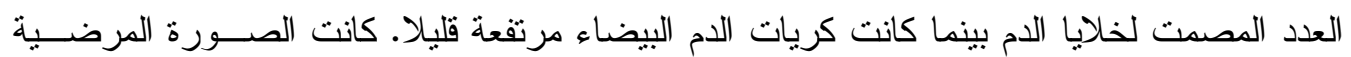

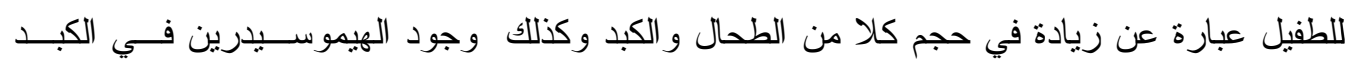
للضأن و المعز المصابة في الذروة و المر احل المتأخرة من الوجود الطن فئل الطيلي في الام. 